\title{
Z VE ALFA KUŞAĞI ILE DiJITALLEŞEN TURIZM
}

\section{DIGITALIZED TOURISM THROUGH Z AND ALPHA}

GENERATION

Ebru BAĞÇI

Adnan Menderes Üniversitesi

ebrubagci@beykent.edu.tr

ORCID: 0000-0002-2763-069X

\author{
Dr. Öğr. Üyesi Onur içöz \\ Adnan Menderes Üniversitesi \\ onur.icoz@adu.edu.tr \\ ORCID: 0000-0002-0775-1451
}

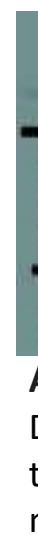

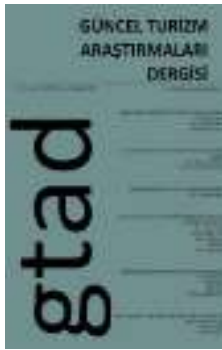

ABSTRACT

MAKALE BiLGISi

Literatür Araştırması

Makale Geliş

17. 06. 2019

Düzeltme

04. 08. 2019

15.08.2019

Kabul Tarihi

16. 09. 2019

Digitalization has gained its importance in tourism sector as in many other fields and most of the tourism businesses and services use digital channels and platforms to promote themselves and to reach their customers. In other words, digital channels are becoming an integral parts of tourism system. For this reason, in this theoretical study, the concept of digitization in tourism, the role of $Z$ generation on this sector with the differences from previous generations were emphasized and the examples of the digitalizing tourism sector were discussed. The literature on the $Z$ and the Alpha generations was reviewed in the reshaping today's business environment which will be at very different points in the near future. Accordingly, the studies on the potential changes that may occur in tourism sector in the future were examined. As conclusion, the ways of doing business that will affect the $Z$ and Alpha generations changing from the past to the present was pointed out and the suggestions about the topic were developed. It was observed that the number of studies on digitalization in the field of tourism is somewhat limited in the literature and it is expected that this study will be the basis for some future studies.

Key words: Z Generation, Alpha Generation, Technology, Artificial Intelligence, Digitalization in Tourism.

Atıf için: Bağçı, E. ve Içöz, O. (2019). Z ve Alfa Kuşağı ile Dijitalleşen Turizm. Güncel Turizm Araştırmaları Dergisi, 3(2), 232-256. 


\section{GíRiş}

Dünyada 1990'larda başlayan küreselleşme ile birlikte toplumun yapısında, yaşam biçimlerinde, üretim ve tüketim alışkanlıklarında da birtakım değişiklikler meydana gelmiştir. İlk olarak, 18. yüzyıldaki Fransız Devrimi ile toplumsal yapıda atılan değişim temelleri, zaman içerisinde endüstri alanlarındaki üretim, tüketim ve ekonomik yapıları da farklılaştırmıştır. 1949 yılında ilk bilgisayar olan ENIAC'ın üretilmesiyle birlikte dünyada dijital devrimin başladığı bilinmektedir (İşman, 2001: 4). Zaman içerisinde internet ve makinelerin bir araya getirilmesiyle süreç hız kazanmıştır. 20. yüzyılın sonlarına doğru gelindiğinde de, bilgi ve teknolojideki gelişimin büyük bir hız kazanmasıyla birlikte dijitalleşmenin önemi son derece artarak, üretim tarzında ve yapısında ciddi bir dönüşüm süreci ortaya çıkmıştır. Günümüzde de bu dönüşüm ve değişimin etkileri devam etmekte olup, geçmiş dönemlere kıyasla bilgi, teknoloji ve makineleşmenin bireylerin yaşantılarına ve endüstriye etkisi giderek artmakta ve bütünsel bir dönüşüm kendini göstermektedir. Yaşanan bu dönüşümler ile birlikte, endüstrinin insan gücünden makineye geçmesiyle başlayan endüstri devrimleri serisi başlamıştır. Endüstri devriminde gelinen son nokta ise Endüstri 4.0 olarak adlandırılmaktadır (Topsakal vd., 2018; 3). Endüstri 4.0'ın turizm alanında kendisini göstermesi ile birlikte de Turizm 4.0 kavramı sektörde yaygın bir şekilde kullanılmaya başlamıştır (Tüzünkan, 2019: 521)

Silahlarla yapılan devrimleri geçmişte bırakan insanlık artık dijital devrimlerle birçok alana yayılıp, varlıklarına değer katmaya çalışmaktadır. İçinde yaşamakta olduğumuz dijital çağda bu devrimlerden etkilenerek değişim yaşayan sanayi sektörünün yanında, diğer tüm sektörler de çeşitli değişikliklere uğramış ve sanayi sektörü dijitalleşme ile birlikte adeta kendi içerisinde farklı bir sektör durumuna gelmiştir. İletişim teknolojilerindeki değişiklik ve bu değişikliğin hızlı bir yayılma göstermesi, sosyolojik olarak önemli olayları beraberinde getirmiştir. Artık, sınırlı bilgi döneminden geniş bilgi havuzlarının olduğu dijital bir çağa geçilmiştir. Bu süreçte sektörlerin bilgi toplama süreçleri ve iletişim süreçleri ve buna paralel olarak kuşakların yaşam tarzları da değişmeye başlamıştır.

Dijital çağda, sektörlerde yaşanan bu değişimin temel nedenlerinden biri olarak gösterilen yapay zekâ uygulamaları; sosyolojik, politik, ticari ve daha birçok alanda değişimi hızla arttırmaktadır (Kayıkçı ve Bozkurt, 2018). Bu bağlamda önceki kuşaklar bu hızlı değişime uyum sağlama konusunda birçok sorunu yaşarken, yeni kuşakların sürece çok daha hızlı uyum sağlayacağı ön görülmektedir. Bu teknolojik değişimler ve yenilikler, Bebek Patlaması (Baby Boomers) olarak adlandırılan II. Dünya Savaşı sonrası

$Z$ ve Alfa Kuşağı ile Dijitalleşen Turizm 
Ebru BAĞÇI ve Onur içöz, 3 (2) 2019

- 234 doğan (1946-64) kuşak ile ardından gelen X (1965-79) ve Y (Millenial, 19801999) kuşakları gibi kuşakların fazlaca şaşırmasına neden olsa da, Z (Milenyum/internet Kuşağı, 2000-2012) ve Alfa kuşakları(2013-2030) için fazla olağan ve beklenen bir durumdur. Çünkü, özellikle Z kuşağı teknolojiyi yoğun olarak kullanan ve seven, internet aracılığıyla sosyalleşen ve mobil teknolojilerle sürekli etkileşimde olan kişilerden oluşur. Gelecek yılların kuşağı olarak kabul edilen Alfa kuşağında bu durumun daha da yoğun olması beklenmektedir. Dijital çocuklar olarak da tanımlanan ve oyuncakları da elektronik olan Alfa kuşağı henüz çocukluk yaşlarında bulunmalarına karşın, dijital teknolojilere fazlasıyla aşinadırlar ve dijital ortamların adeta onların yaşamlarının ayrılmaz bir parçası durumuna geleceği düşünülmektedir. Bunun temel nedeni de, $Z$ ve Alfa kuşaklarının hâlihazırda toplum yaşamında mevcut bulunan dijital dünyada ve internet döneminde dünyaya gelmiş olmalarıdır. Ayrıca bu kuşaklar dünyaya geldiklerinde zaten uzaya çıkılmış ve uzak bölgelerden görüntülü iletişim ve görüşmeler yapılmıştı. Yani Z ve Alfa kuşağının yaşam tarzlarını şekillendiren baskın unsur teknoloji ve teknolojik gelişmelerdir. Tıp alanında hastalıklara tanı koymaktan, uzaktan eğitim olanaklarından faydalanmaya ve sosyal hizmet, alışveriş, robot teknolojileri, vatandaşlık hizmetlerine kadar birçok gelişmenin yaşandığı bu dönemde neredeyse teknolojik gelişme ve internetin girmediği alan kalmamıştır. Bu kadar farklı alanda varlığını sürdüren teknolojinin elbette ki turizm alanında hizmet veren farklı kollardaki işletmeler üzerinde de etkisi olmuştur.

Yukarıda söz edilen gerekçelerle, bu çalışma her geçen gün sosyal yaşamda ve iş yaşamında etkisini ve ağırlığını artıran dijitalleşme ve dijital platformların en etkili kullanıcı olan ve olması beklenen $Z$ ve Alfa kuşaklarının turizm hizmetlerini hangi şekillerde ve nasıl kullanabileceğini irdelemeyi amaçlayan kavramsal bir derleme çalışması olarak tasarlanmıştır.

\section{KAVRAMSAL ÇERÇEVE VE LITERATÜR}

Turizmde dijitalleşme ve teknolojik gelişmelerin tüketici olarak tanımlanmış olan $X, Y$ ve $Z$ kuşağı turistlerin ya da ziyaretçilerin seyahat kararı aşamasından, hizmet kullanımı ve turizm deneyimi aşamalarına kadar her aşamada tüketim tarzlarını nasıl etkilediğine ilişkin birçok çalışma yapılmıştır. Aşağıda yer alan 1 numaralı tabloda bu konuda yapılmış olan bazı çalışmaların bir listesi görülmektedir. 
Tablo 1. Türkiye'de ve Dünya'da Kuşaklar, Dijitalleşme ve E-Turizm Konusunda Yapılan Başlıca Çalışmalar

\author{
Çalışmanın Adı Erol G. (2017), X, Y ve Z Kuşağı Tüketicilerinin Satın Alma Davranışları \\ Üzerine Pilot Bir Araştırma.
}

\begin{tabular}{|c|c|}
\hline Amaç & $\begin{array}{l}\text { Bu araştırmanın amacı; pazarlama bilimi araştırmalarında sıkça rastlanan } \\
\text { kuşak kavramının neden bu kadar önemli olduğuna ve kuşaklar arası } \\
\text { süreçte özellikle satın alma davranışlarında sosyoekonomik, psikolojik gibi } \\
\text { değerlerin kişileri nasıl etkilediğine değinmektir. }\end{array}$ \\
\hline Yöntem & $\begin{array}{l}\text { Bu araştırmada nicel/sayısal araştırma yöntemlerinden faydalanılmıştır. } \\
\text { Araştırmaya yönelik veriler alan araştırması yöntemi kapsamında anket } \\
\text { tekniği ile elde edilmiştir. Araştırmada " } X \text { ve } Y \text { kuşağının satın alma } \\
\text { davranışlarının incelenmesi veri toplama formu (anket)" kullanılmıştır. }\end{array}$ \\
\hline
\end{tabular}

\begin{tabular}{ll}
\hline Sonuç & Katılımcılar düzenli gelire sahip kişilerden oluşmaktadır. \\
& - Gelirlerinin belli oranını alışverişe ayırdıklarını belirtmişlerdir. \\
& - X ve Y kuşağı alışverişe aileleriyle çıkmaktadırlar. \\
- Alışveriş esnasındaki aldıkları kararlarda ailelerinden & etkilenmektedirler. \\
- Vitrin renkleri satın alma tercihlerini etkilemektedir. \\
- Ürünün markası ve fiyatı tercihleri açısından önemli bir etken \\
- oluşturmaktadır.
\end{tabular}

$Z$ ve Alfa Kuşağı ile Dijitalleşen Turizm

Çalışmanın Adı Biztatar, H. (2017), Olumsuz Elektronik Ağızdan Ağıza Pazarlama iletişimine Etki Eden Faktörler: Z Kuşağı Tüketicilerinin Görüşlerini Belirlemeye Yönelik Bir Araştırma

Amaç

Z kuşağı tüketicileri için dijital/elektronik ortamlar, diğer kuşaklara oranla daha fazla olumlu ve olumsuz paylaşım yapılan ortamlar olarak bilinmektedir. Yapılan olumlu ağızdan ağıza pazarlama çalışmalarıyla birlikte, olumsuz ağızdan ağıza pazarlamaya ilişkin ilgili yazın alanı incelendiğinde sınırlı sayıda çalışmaya rastlanmaktadır. Bu bağlamda bu çalışmada olumsuz elektronik ağızdan ağıza pazarlama niyetine etki eden faktörlerin kuşağı tüketicilerinin görüşlerini belirlemesi amaçlanmıştır.

Yöntem

$\mathrm{Bu}$ araştırmada nicel/sayısal araştırma yöntemlerinden faydalanılmıştır. Araştırmaya yönelik veriler alan araştırması yöntemi kapsamında anket tekniği ile elde edilmiştir.

Sonuç

- Farklı kültürlerde aynı ölçeklerle yapılan çalışmaların farklı faktörler altında toplanabildiği ve farklı sonuçlar ortaya çıkardığı belirlenmiştir.

- Z kuşağı üzerinde uygulanan bu çalışmada teknik beceri ve sosyal medya aynı boyut altında toplanmıştır ve teknik beceri ve sosyal medyanın olumsuz elektronik ağızdan ağıza pazarlama üzerinde etkisi olduğu ortaya çıkmıştır. 


\section{Z ve Alfa Kuşağı ile Dijitalleşen Turizm}

Çalışmanın Adı Sarı, S., Gürsoy S. ve Özmen M. (2016), Y Kuşağının Çevrimiçi Satın Alma Davranışları.

Amaç Çevrimiçi alışveriş ve araştırma yapanların büyük çoğunluğunu $Y$ kuşağı mensuplarının oluşturduğu görülmektedir. Bu yüzden bu kuşağın satın alma davranışlarını anlamak ve bunlara yönelik pazarlama stratejileri oluşturmak, işletmelere bu anlamda rehber sunmak amacıyla bu çalışma hazırlanmıştır.

Yöntem Bir alan araştırması niteliğindeki bu çalışmanın örneklemini Mehmet Akif Ersoy Üniversitesi'nde ön lisans ve lisans düzeyinde eğitim görmekte ve 1980-1999 yılları arasında doğmuş 443 üniversite öğrencisi oluşturmaktadır. Tesadüfi örneklem yöntemiyle katılımcılara uygulanan anket tekniği ile veriler elde edilmiştir.

\section{Ebru BAĞÇI ve Onur içöz, 3 (2) 2019}

- 236
- Y kuşağının genel olarak çevrimiçi alışverişe olumsuz bakmadıkları tespit edilmiştir.

- Çevrimiçi alışverişin risk barındırdığını farkında oldukları ancak satın alma davranışından kaçınmadıkları tespit edilmiştir.

- Gelir durumlarına göre çevrimiçi alışverişten kaçınma düzeyleri ölçümlenmiştir ve gelir durumuna göre alışverişten kaçınma durumunda farklılıklar olduğu sonucuna varılmıştır.

- Kredi kartı kullanımı yapan Y kuşağı katılımcıları kredi kartı kullanmayan $Y$ kuşağı katılımcılarına oranda çevrimiçi alışverişten kaçınmaktadırlar.

Bu kuşağa mensup erkek katılımcılar kadın katılımcılara kıyasla çevrimiçi alışverişten daha az kaçmaktadırlar.

Çalışmanın Adı Szopiński, T. ve Staniewski M.W. (2016). Socio-economic factors determining the way e-tourism is used in European Union member states.

Avrupa Birliği üyesi ülkelerde e-turizm kullanma şekillerini etkileyen sosyoekonomik faktörler.

Amaç

Çalışmanın amacı; farkıı Avrupa Birliği üyesi ülkelerde internet kullanıcıları tüketicilerin e-turizm kullanım sıklığını test etmek ve bu sıklığı etkileyen sosyoekonomik değişkenleri belirlemektir.

Yöntem

Çalışma alan araştırması ve ikincil veri analizini içermekte olup, 28 AB üyesi ülkeye ilişkin veriler ile 25,000 katılımcıya ilişkin analiz edilmiştir. Bu veriler söz konusu ülkelerdeki e-turizm kullanım sıklığı ile ilgili faktörleri içermektedir. Her ülke için örneklem olarak belirlenen internet kullanıcıları çevrimiçi paneller ile araştırmaya dahil edilmiştir. Ayrıca bir ülke için de CATI yöntemi (internet destekli telefon görüşmesi) uygulanmıştır.

Sonuç

- Çalışmanın yazarları internet kullanıcılarının e-turizm kullanımı ile orjin ülke arasında istatistiksel olarak anlamlı ilişkiler belirlemiştir.

- Ayrıca e-turizm kullanım sıklığı ile yaş, cinsiyet, eğitim düzeyi, meslek ve mesleki konum arasında da anlamlı ilişkiler bulunmuştur. 
Çalışmanın Adı Xiang, Z. (2018). From digitization to the age of acceleration: On information technology and tourism.

Dijitalleşmeden hız çağına: teknoloji ve turizm enformasyonu üzerine.

\begin{tabular}{ll}
\hline Amaç & $\begin{array}{l}\text { Çalışma 1997-2006 arasındaki dijitalleşme çağından, 2007-2016 arası } \\
\text { hızlanma dönemine geçiş ve her iki } 10 \text { yıllık dönemde dijital } \\
\text { teknolojilerdeki gelişmeler ve bu gelişmelerin toplumu ve ekonomiyi nasıl } \\
\text { yönlendirdiğini incelemektedir. }\end{array}$ \\
\hline Yöntem & İkincil kaynak taraması ile yapılmış kuramsal bir derleme çalışmasıdır. \\
\hline Sonuç & $\begin{array}{l}\text { Çalışma akıllı telefonlar, dronlar, giyilebilir teknolojiler, yeni iletişim türleri } \\
\text { ve büyük veri gibi alanlardaki gelişmelerin turizmde enformasyon } \\
\\
\text { şekillerini nasıl değiştirdiği ve gelecekteki olası araştırma sorunları ve } \\
\text { zorlukların neler olabileceği konusunda yorumları kapsamaktadır. }\end{array}$
\end{tabular}

Çalışmanın Adı Haddouche H. ve Salomone, C. (2017). Generation Z and the tourist experience: tourist stories and use of social networks.

Z Kuşağı ve turist deneyimi: turist öyküleri ve sosyal medya kullanımı.

Amaç Bu çalışmanın amacı Z kuşağı mensuplarının turizm deneyimleri ve daha özelde kendi turist deneyimleri ve sosyal medya kullanımlarını anlamaktır. Çalışma ayrıca Z kuşağının sürdürülebilir turizm kavramını nasıl algıladığını da sorgulamaktadır.

$Z$ ve Alfa Kuşağı ile Dijitalleşen Turizm

Yöntem

Çalışmada yazarlar nitel bir araştırma yapmışlardır. Araştırma protokulü 2 aşamalı yürütülmüştür. İlk aşamada yazarlar 6 yarı yapılandırılmış soruyu 1995-2002 arası doğanlara yönlendirmiş. İkinci aşamada ise yazarlar öyküye dayalı araştırma yöntemi ile 1995-1997 arası doğmuş olan 37 öğrenciye kendi seyahat deneyimlerini anlatan kısa öyküler yazmalarını istemiştir.

Sonuç

- Her ne kadar kendileri narsistik, selfieler (özçekim) paylaşmak gibi kendi önceliklerini ilk planda düşünen bir kuşak olarak sunulsa da, bu çalışma Z kuşağının kendi seyahatlerinde büyük bir tevazu gösterdiğini ortaya koymuştur.

- Ayrıca, sonuçlar sürdürülebilir turizmin görüşme yapılan öğrenciler için önemli bir kavram olmadığını da göstermiştir.

Çalışmanın Adı Titan, L.S., Sanjaya ve Ferdianto. (2016). Influential Factors on Travel Decision in E-Tourism.

E-Turizmde seyahat kararını etkileyen faktörler.

Amaç Çalışmanın amacı, çevrimiçi turizm tanıtımlarının nasıl yapıldı̆̆ının ve
kişilerin çevrim içi seyahat satın almalarını etkileyen faktörlerin
belirlenmesi ile ideal bir e-turizm modelinin oluşturulması olarak
belirtilmiştir.

Yöntem

Çalışmada anket tekniği ile veri toplamaya dayalı bir alan araştırması yöntemi kullanılmış ve 200 denek üzerinde çalışma yürütülmüştür. 
Sonuç

Ebru BAĞÇI ve Onur içöz, 3 (2) 2019

- 238

- Araştırmada e-turizm bakımından satın alma kararlarını pozitif yönde etkileyen faktörler olarak, acente tavsiyesi, destinasyonlar ile ilgili bilgilerin elde edilmesi, e-ticaret özelliği, erişim kolaylıkları, karşılaştırma olanakları ve sosyal medya değişkenleri belirlenmiştir.

- Bununla birlikte negatif etki oluşturan değişkenler de coğrafi bilgi sistemleri ve tur paketleri belirlenmiştir. Yanıt verenler tur paketlerini fazla kısıtlayıcı olarak, coğrafi bilgi sistemlerini ise bağlantı ve yanlış yönlendirme sorunları ile yargılamıştır.

Tfaily R.A. (2018). E-Tourism and the competitiveness of tourism products in the context of the global tourism and travel industry Market.

E-Turizm ve küresel turizm ve seyahat endüstrisi pazarı bağlamında turizm ürünlerinin rekabet edebilirliği.

\begin{tabular}{cl}
\hline Amaç & $\begin{array}{l}\text { Çalışmanın amacı, küresel bağlamda e-turizmin turizm ürünlerinin rekabet } \\
\text { gücü üzerindeki etkisini analiz etmek olarak belirlenmiştir. }\end{array}$ \\
\hline Yöntem & Çalışma literatür taramasına bağlı kuramsal bir derleme niteliğindedir. \\
\hline Sonuç & CÇalışmanın temel bulguları; inovasyonun turizmde büyük önem taşıdığı \\
& $\begin{array}{l}\text { ve bilgi teknolojilerinin ürün geliştirmede bir dizi fırsat yarattığı, ancak } \\
\text { seyahat endüstrisinin birer parçası olan örgütler(firmalar) için bazı } \\
\text { riskleri de bünyesinde barındırması olarak sunulmuştur. }\end{array}$
\end{tabular}

Kaynak: Yazarlar tarafından derlenmiştir.

Tablo 1'de yer verilen ve tamamı 2016 ve sonrasında yapılmış olan çalışmalar e-turizm, dijitalleşme, seyahatlerde internet kullanımı ve farklı kuşaklar arasındaki ilişkileri ölçmeyi amaçlayan çalışmalardır. Bu çalışmalardan Türkçe olarak hazırlananlar, genellikle pazarlama alanı kapsamında kuşakların dijital ortamlar üzerinden satın alma eğilim ve davranışlarını inceleme amaçlı ve deneysel saha (alan) araştırmaları ile sonuçların elde edilerek tartışıldığı çalışmalardır. Türkçe çalışmalardan iki tanesi bu çalışmanın da konusu olan Z kuşağı ile ilgili, fakat turizm alanı dışında ve yine pazarlama alanına yönelik çalışmalardır. Bu Türkçe çalışmaların başlıca bulgularına göre; dijital ortamları satın alma aracı olarak kullanan kuşakların gelir ve eğitim düzeylerinin iyi olduğu, ürün markalarına karşı duyarlı oldukları, "elektronik tavsiye" adı da verilen internet sayfalarındaki tavsiye mesajlarını dikkate aldıkları (e-WOM) ve özellikle negatif tavsiyelerden daha fazla etkilendikleri, $Y$ kuşağının "çevrimiçi alışveriş" konusunda daha kuşkucu olduğu, bu alışverişlerin belli bir risk taşımasına karşın, yine de bu ortamlardan alışveriş yapıldığı ve $Y$ kuşağı erkeklerinin dijital ortamlardan satın alma eğilimlerinin daha fazla olduğu belirlenmiştir.

$\mathrm{Bu}$ çalışmalar kuşkusuz turizm alanı dışında yapılmıştır, ancak turizm alanındaki tüketicilerin de benzer davranış şekilleri gösterebileceğini 
belirtmek mümkündür. Bu konuda temel farklılık kuşkusuz turizm ürünlerinin baskın bir şekilde hizmet şeklinde sunulmasıdır. Hizmetlerin tüketici açısından satın alma riski oluşturan en belirgin özelliği de soyut olması ve önceden deneme olanağı tanımamasıdır. Bu nedenle, diğer somut ürünlerde olduğu üzere dijital ortamlarda satın alınan ürünlerde uygulanan iade uygulaması söz konusu olamamaktadır (İçöz, 2001: 31). Eturizm ve satın alma davranışları üzerine yapılan uluslararası çalışmalara bakıldığında da, internet kullanımı ve dolayısı ile e-turizme olan talep bakımından etkili olan sosyo-ekonomik faktörler, sanal ortamlarda turizm ürünü geliştirme ve inovasyon olanakları, e-seyahat kararları ve etken faktörler, turizmde enformasyon teknolojilerinin etkin kullanımının ön plana çıktığı tespit edilmiştir. Uluslararası bu çalışmalardan biri ise doğrudan Z kuşağı üzerine yapılmış bir çalışma olup, bu çalışma Z kuşağının özellikle sosyal medya kullanımı ve bu sayede seyahat deneyimleri üzerine yapılmış bir araştırma ve sonuçlarını içermektedir (Haddouche ve Salomone, 2017).

Literatür incelemesinden de görüleceği üzere, doğrudan Z kuşağı ve bir sonraki kuşak olacak olan Alfa kuşağı ile dijitalleşme konusunda yapıımış olan oldukça az sayıda çalışma vardır. Bu nedenle eksikliği hissedilen bu konuda yapılan bu çalışmada dijital ortamlarda turizm hizmetlerinin mevcut kuşaklara sunumu ile şimdinin ve geleceğin turizm talebini oluşturan $Z$ ve Alfa kuşaklarının dijital ortamlarda bu hizmetleri nasıl talep edeceği ve kullanacağına ilişkin yaklaşım ve analizlere yer verilecektir.

\section{Turizm ve Dijitalleşmeye Kuramsal Yaklaşım}

\section{Endüstri 4.0 ve Etkileri}

Teknoloji ve teknolojik gelişmeler tarihsel süreçte üretim şekillerini ve toplumsal yaşamı 4 farklı dönemde etkileyerek değiştirmiştir. ilk olarak 18. yüzyılda üretimde buharlı makinelerin kullanılmasıyla birlikte bu dönüşüm başlamış ve 1. Endüstri Devrimi adı verilen sanayileşme (1760-1830), daha sonra 20. yüzyılda seri üretimde elektriğin ve ulaşımda içten yanmalı motorların kullanılmasıyla 2. Endüstri Devrimine evrilmiştir. 1970'li yıllarda elektronik ve bilgisayarların kullanılmaya başlanması ile üretimin otomasyonu anlamına gelen 3. Endüstri Devrimi başlamış ve son olarak da içinde bulunduğumuz yüzyılda bilgi, bilişim ve iletişim teknolojilerinde yaşanan gelişmeler, fiziksel ve dijital sistemler arasında bağlantı kurarak üretim süreçlerini insansız biçimde de kullanılabilen (otonom makinalar, sanal ortamlar, yapay zeka vb.) yeni üretim sistemleri anlamına gelen 4 . Endüstri Devrimini yani Endüstri 4.0 kavramı ortaya çıkmıştır (Kagermann vd., 2013; Şahin ve Yağcl, 2017; Soylu, 2018 ). Endüstri 4.0, inovasyon odaklı olup hı, maliyet, ergonomi, uyumluluk ve verimlilik alanlarında 
Ebru BAĞÇI ve Onur içöz, 3 (2) 2019

- 240 sürekli gelişen uyumlu, bütünleşik ve yüksek bir teknoloji düzeyini ifade etmektedir. Dijitalleşme sayesinde, birbiriyle hızlı biçimde iletişim kurabilen birçok cihaz, veri işleme gibi bir dizi faktörleri öne çıkarmaktadır (Soylu, 2018). Ayrıca, nesnelerin interneti, yapay zekâ, nano-teknoloji, sanal (arttırımış) gerçeklik, robotlar, 3D yazıcılar gibi yeni nesil teknolojiler de bu kavram altında yer almaktadır (Topsakal vd., 2018)

Endüstri 4.0 kapsamındaki teknolojik gelişmelerin diğer üretim alanlarında olduğu gibi, turizm hizmet sunucularının ve işletmelerinin kârlılığı üzerinde önemli etkileri olacağı düşünülmektedir. Bu nedenle Endüstri 4.0'ın turizm alanına uyarlanması ile bazı yazarlar, "kişiselleştirilmiş seyahat deneyimi yaratmak için, turizm ve seyahat endüstrisindeki hizmetlerden faydalanmış çok sayıda kişiden toplanan büyük verilerin işlenme süreci" anlamına gelen Turizm 4.0 kavramını da gündeme getirmişlerdir (Tüzünkan, 2019: 521). Büyük veri kavramı son dönemlerde turizm işletmelerinin çok sayıda veriyi sosyal medyadan elde etmesinden dolayı "Sosyal Büyük Veri" olarak da kullanılmaya başlamıştır (Del Vecchio vd., 2018). Uzmanlara göre, internetin gelişimi ile birlikte web teknolojilerinde ve mobil uygulamalarda yaşanan etkilerden çok daha fazlasının turizm sektöründe dönüştürücü etkilerinin olacağı ön görülmektedir (Mil ve Dirican, 2018). Yeni üretim sistemlerin ortaya çıkmasıyla bireylerin yaşam biçimlerinde, istek, ihtiyaç ve tüketim alışkanlıklarının değişiklik göstermesinde önemli bir faktör olmaktadır. Tüm sektörlerde olduğu gibi turizm endüstrisi için de, değişimlere uyum sağlayabilmek ve turizm endüstrisi içinde bulunan diğer işletmelerle rekabet edebilmek için bu değişimleri doğru analiz etmek ve analiz neticesine göre değişimi uygulamak önemlidir (Şahin ve Doğdubay, 2017). Hâlihazırda bazı ülkeler dış tanıtımlarında ve farklı projelerinde Turizm 4.0'dan faydalanmaktadırlar. Örneğin, Malezya Turizm 4.0 kullanımının turizm sektöründe dijital teknoloji kullanımını arttıracağını ve bunun turist deneyimlerinde gelişme sağlayacağı fikrinden hareketle, özellikle Çin'den gelecek turist sayısında artış olacağını ve turizm sektöründe iş imkânlarını geliştirerek ekonomiye de katkı sağlayacağını öngörmektedir (Tüzünkan, 2019, 521).

Günümüz tüketicileri dikkate alındığında, Endüstri 4.0'a kısmen uyum sağlan $Y$ kuşağı ile ve bu değişime bütünüyle uyum sağlamış olan $Z$ Kuşağının tüm sektörlerdeki arz ve talebin temel belirleyicileri olduğu söylenebilir. Özellikle, sanal ortamları ve interneti eksiksiz kullanabilen ve bilgisayar okur-yazarlığı çok yüksek olan Z Kuşağının tüketim alışkanlıklarının bilinmesi, turizmin de dâhil sektörlerin gelecek ile uyumlu biçimde büyüme göstermelerini sağlayacaktır. 


\section{Dijitalleşme ve Turizm}

Turizmde bilgi ve iletişim teknolojileri öncelikle telefonların ve diğer haberleşme sistemlerinin daha sonra da bilgisayarların kullanımı ile kendisini göstermiş olsa da, dijitalleşmenin ilk kuşak e-platformları olarak kabul edilen Küresel Dağıtım Sistemleri (GDS) ve Teletext'in bu sektörde kullanılması ve hızla yaygınlaşması ile 1980 'li yıllarda sıçrama yapmıştır. 1990 'ı yıllarda ise ikinci kuşak e-platformlar olarak adlandırılan çevrimiçi seyahat siteleri (Expedia gibi), çevrimiçi tur operatörleri, havayolu işletmeleri ve mezat siteleri (eBay, Lastminute gibi) sektörde ağırlığını hissettirmeye başlamıştır. E-platformların üçüncü kuşağı olarak tanımlanan 2000 sonrası dönemde (Milenyum kuşağı e-platformlar) ve günümüzde mobil teknolojiler, sosyal medya platformları ve sanal turlar turizmin önemli dijital ortamları olarak kullanılmaktadır (Page, 2009: 232). Üçüncü kuşak e-platformlar ve dijitalleşmenin günümüzde ulaştığı aşamada ise yapay zekânın sektörde kullanımı aşamasına geçilmiştir. Örneğin, konaklama işletmeleri (otel vb.), müzeler, havalimanları, yiyecek-içecek işletmeleri ve benzeri birçok üretim alanı, uzmanlar tarafından self-servis teknolojinin ve çeşitli hizmetlerin sunulmasına destek verebilen yarı kontrollü robotların test alanı olarak kullanımına çok uygun yerler olarak ortaya çıkmıştır (Ivanov ve Webster, 2017).

Hâlihazırda servis robotları, 7/24 çalışan self servis kioskları, yapay zekâ temelli chatbotlar ve benzeri digital destekli birçok ürünler şeklinde bugün turizm alanında geniş bir şekilde hizmet verilebilmektedirler. Bu hizmetler de; sınırsız çalışma süreleri, ilk edinim ücretleri ile birlikte aralıklı servis bakım ücretleri dışında düzenli maaş gibi sürekli masrafları olmamaları bakımından insanlardan daha verimli sunulabilmektedirler (Ivanov ve Webster, 2017). Turizmde dijitalleşme konusu, kamu turizm otoriteleri tarafından da dikkate alınmaya başlamış ve Kültür ve Turizm Bakanlığı tarafından 01-03 Kasım 2017 tarihinde Ankara'da gerçekleştirilen Üçüncü Turizm Şurası'nda da "Dijital Turizm ve İnovasyon Komisyonu" yer almıştır. Bu komisyonda yapılan görüşmelerde ülke, destinasyon ve ürün bazında turizm sektöründe yapılacak teknoloji yatırımları ve kısa, orta ve uzun dönemli dijital kampanya stratejilerinin oluşturulması amaçlanmıştır (Üçüncü Turizm Şurası, 2017: 98). Böylece turizm endüstrisi için, dijitalleşme kavramının gelişen yeni ve önemli bir kavram olduğu gerçeği kamu ve özel sektör tarafından geniş bir kabul görmeye başlamıştır.

Uzmanlara göre, turizm sektörü dijitalleşme trendine ilk dâhil olan sektörlerden biridir. Dubey (2017), turistlerin tercih ve deneyimlerinin değiştiğini ifade ederek, sanal gerçeklik kavramı ve 3D yazıcıların desteğiyle turistlerin farklı deneyimleri (hayvan derisi okşama, kaplana sarılma vb.) bu

$Z$ ve Alfa Kuşağı ile Dijitalleşen Turizm

- 241 
Ebru BAĞÇI ve Onur içöz, 3 (2) 2019

- 242 teknolojiler ile yaşayabileceğini belirtmiştir. Bu konuda yapılan bir diğer çalışmada, turizm endüstrisinde kullanılan akıllı uygulamalardan, arttırılmış gerçeklik, e-acenta, 3D yazıcılar, hologramlar ve tur satın almadan önce turistlere deneme imkânı sağlayan yapay zeka destekli uygulamaları ve dijital akıllı seyahat arkadaşlarından söz edilmiştir (Soava, 2015). Turizmde dijitalleşmenin önemli uygulama alanlardından biri de, turizm faaliyetlerine katılmak isteyip de katılamayan engelli bireylerin yaşamlarını kolaylaştıracak olan olanaklar sunulmasıdır. Konuya ilişkin çalışmalarda Robot, Avatar ve Hologram gibi uygulamaların engelli bireylerin seyahate katılmalarını kolaylaştıracağı ve seyahate katılma taleplerinin artacağı ifade edilmektedir (Cheung vd., 2017).

Benzer şekilde, Turizm 4.0 kapsamında geliştirilen sanal turların, özellikle destinasyon ve müze ziyaretlerinde kullanımı her geçen gün artmaktadır. Dünyanın en önemli müzelerinden olan Londra British Museum ve New York Metropolitan Museum dijital ortamlarda sanal turlar düzenleyerek geniş kitlelere ulaşmış ve uluslararası bir çekicilik kazanmıştır (Durmaz vd., 2018). Sanal turların yanı sıra, turizmde robotların kullanımı turistler ve aracılar arasındaki iletişimi daha iyi bir duruma getirerek, ziyaretçilerin seyahate çıkma konusundaki en önemli sorunlardan biri olan yabancı dil sorununu da çözeceği belirtilmektedir (Nieto vd., 2014). Kayıkçı ve Bozkurt (2018) da yapay zekâ uygulamalarının, tüm turistlerin kendi ana dillerinde hizmet almalarını sağlayarak seyahatlerini daha rahat gerçekleşeceklerini belirtmişlerdir. Dijital pazarlama ile uygulama alanında kendini gösteren turizm sektöründeki ilkler de öncelikle havayolu taşımacılığı, acente ve satış kanallarında yaşanmıştır. Örneğin, Thomas Cook ve Samsung Gear'ın birlikte arttırılmış gerçeklik (augmented reality) uygulaması yaparak, uygulamanın ilk üç ayında konaklama ve uçuşlarda 17 bin dolar (ABD \$) ek gelir elde etmiştir (Hughes, 2016). Öte yandan, çevreci anlayış ve sürdürülebilir turizm yaklaşımı ile turizm tesislerinde bina ve işletme yönetiminde de farklı deneyimler sunan dijital sistemler de kullanılmaya başlanmıştır (turizmajansı.com, 2018).

Turizmde dijitalleşme, genellikle bu gelişmeyi vurgulayan ve sektörde yaygın olarak kullanılan 2 kavram ile kendisini göstermektedir. Bunlardan birincisi; önceki kısımlarda açıklandığı üzere, turizmde dijital platformların yaygınlaşmasını ve kullanımının genişlemesini açıklayan "elektronik turizm" (e-turizm), ikincisi ise; turizmde dijitalleşmenin sağladığı kolaylıkları ve hizmetlerin sunumunun hızlanmasını vurgulayan "akıllı turizm" (smart tourism) kavramlarıdır. Bu bağlamda "akıllı (smart)" kelimesi "problemlerin hızlı, esnek ve doğru bir şekilde anlaşılarak çözümlenmesi" anlamına gelmektedir. (Lee vd., 2017). Bu nedenle de "akıllı turizm" elektronik gereçler ve iletişim araçları ile turizm ve seyahatlere ilişkin sorunların hızla 
anlaşılıp çözümlenmesi ve daha etkili hizmet verilmesi anlamı taşımaktadır. Akıllı turizm de, özellikle işletmeler açısından talep yönetimi, müşteri ilişkileri, daha etkin pazarlama, ürün yönetimi ve planlaması alanlarında (Maudlin, 2019); seyahat edenler açısından da, seyahat planlama (Huang vd. 2017;), ürün karşılaştırma ve özellikle e-tavsiye(e-WOM) alanlarında oldukça etkili bir şekilde kullanılmaktadır.

Dijitalleşmenin bugün geldiği noktadan yola çıkarak; gelecekte otellerde daha fazla yapay zekâ, arttırılmış gerçeklik, kişiselleştirilmiş hizmetler ve robotların kullanıma sunulacağı ön görülmektedir. Bu konuda ilk uygulama örneği olarak, Japonya'da Nagazaki şehrinde açılan dünyanın ilk robot otelinde konuklarını Japonca selamlayarak karşılayan robotlar onlarla sohbet ederek otelin 72 odasına bavulları taşıyabilmektedir (Boneval, 2019). Buradan hareketle, sektörde 25 yılı aşkın süredir hizmet vermekte olan Hotels.com ve Dr. James Canton 2060 yılında konaklama işletmelerinin nasıl olabileceğine dair bir araştırma yapmışlardır. Araştırma bulguları Tablo 2'deki gibi özetlenmektedir.

Tablo 2. 2060' da Oteller Nasıl Olacaktır?

\begin{tabular}{ll}
$\begin{array}{l}\text { Robot } \\
\text { yardımcılar }\end{array}$ & $\begin{array}{l}\text { Konuklar konaklama tesislerine varmadan önce, onların dilini } \\
\text { konuşabilecek şekilde, kş̧iye özel yeteneklerle donatılacak robotlar, } \\
\text { havalimanında karşılama hizmetinden, arkadaşlık hizmetine kadar } \\
\text { her şeyi yapacaklardır. }\end{array}$ \\
\hline $\begin{array}{l}\text { Talebe göre } \\
\text { dönüştürülen } \\
\text { oteller }\end{array}$ & $\begin{array}{l}\text { konukların oy ve yorumlarına göre konaklama tesisleri } \\
\text { tasarlanabilecek ve monte edilebilecek. Konuklar hayalini kurduğu, } \\
\text { hizmetlerinde Nano teknoloji ve gelişmiş makinelerden yardım } \\
\text { alınacak. Bu teknolojinin önümüzdeki 20 yıl içerisinde hayatımıza } \\
\text { girmesi beklenmektedir. }\end{array}$ \\
\hline $\begin{array}{l}\text { Her odada üç } \\
\text { boyutlu yazıcı }\end{array}$ & $\begin{array}{l}\text { Bu teknoloji ile konukların valiz hazırlama sorununa çözüm bulmak } \\
\text { olarak kendi odalarında üretmeleri hedeflenmektedir. }\end{array}$ \\
\hline $\begin{array}{l}\text { Kendi rüyanı } \\
\text { seç }\end{array}$ & $\begin{array}{l}\text { Konaklama tesisleri nöro-teknoloji programları aracılığı ile } \\
\text { konuklarının kendi seçecekleri rüyalarla uykuya dalmalarına } \\
\text { yardımcı olacaklardır. }\end{array}$ \\
\hline Pop-up oteller & $\begin{array}{l}\text { Yeni nesil pop-up otellerin tema ve yerleri, mobil oylama ile halk } \\
\text { tarafından seçilecek. En fazla oyu alan otel tasarımı, yine nano } \\
\text { teknoloji özellikli üç boyutlu yazıcılarla kısa sürede inşa edilecek ve } \\
\text { biyo-güneş pilleri kullanacak şekilde programlanacaktır. }\end{array}$ \\
\hline
\end{tabular}

$Z$ ve Alfa Kuşağı ile Dijitalleşen Turizm 
Bu Spa'larda misafirlerin DNA analizleri yapılarak rahatsızlıkları Ömür uzatan teşhis edilecek. Sonraki aşamada ise, rahatsızlıkların giderilmesi için otel Spa'ları vücuda göre geliştirilmiş programlar sunulacak ve bugün ile kıyaslanamayacak ölçüde rahatlama sağlanacaktır.

Bugün hayatımızda olan Apple'ın Siri'si Amazon'un Alexa'sının daha Seyahat kişiselleştirilmiş bir sürümü olarak tasarlanacak, kişisel avatarımız, Avatarı $^{1}$ desteği rezervasyonlarımızı tasarlayıp, gerçekleştirecek ve yönetecek, bir nevi kişisel seyahat acentemiz gibi çalışacaktır.

Enerji verimliliği artacak ve yenilebilir enerji platformları devreye Eko-oteller girecektir. Gelişmiş güneş enerjisi ve jeotermal enerji teknolojileri ile donatılacak eko-oteller, ürünlerinden çalışanlarına sosyal farkındalık oluşturarak topluma katkı sağlayacaktır.

Ebru BAĞÇı ve Onur içöz, 3 (2) 2019

- 244

\begin{tabular}{ll}
\hline $\begin{array}{l}\text { Arttırılmış } \\
\text { Gerçeklik }\end{array}$ & Artırılmış gerçeklik sayesinde inovatif (yenilikçi) senaryolar \\
otelleri & geliştirilecek ve örneğin, Avrupa'daki bir otelde kalan bir konuk, \\
& otelde kalışı sırasında Afrika'daki sanal bir geziye çıkabilecektir.
\end{tabular}

Otel restoranları, DNA analizleri doğrultusunda kişinin damak tadına Farklı bir lezzet en uygun ve en çok beğeneceği yemekler servis edecektir. Konuk deneyimi otele varmadan, DNA özelliklerine göre sağlığı için optimize edilmiş, kişiye özel diyet ve beslenme menüsü hazır olacaktır.

Geleceğin otelleri sürükleyici temalar ve bugün sadece hayal Sürükleyici edebileceğimiz deneyimler sunacaktır. Gezginler, ayrıca gerçek temalı oteller zamanlı interaktif etkinliklere de katılabilecektir. Örneğin, Roma ya da Rönesans döneminde vakit geçirebilecek şekilde sanal gerçeklik deneyimlerine katılabilmek mümkün olacaktır.

Otellerde odaya girişte yüz tanıma sistemi, kişiyi takip eden çoklu sensörler, konuşan ve kişiye yanıt veren televizyonlar, tümüyle dokunmatik, reaktif ve interaktif yüzeyler, akıllı tuvaletler ve gerçek zamanlı haber akışı sunan aynalar, stres düzeyini algılayarak Akıllı otel rahatlatıcı aromalarla odadaki havayı gevşeten, uykuyu rahatlatan interaktif duvarlar, kir tutmayan özel nano kaplamalı havlular, otomatik olarak ayarlanan, kablosuz sıcaklık kontrolleri, nörogeribildirime dayalı kişiselleştirilmiş yatak ve yastıklar, hologram konser veya spor karşılaşması izlemek gibi oda içi kişiselleştirilmiş deneyimler olacaktır.

Kaynak: Taşçı, M. (2018)

Tablo 2 gelecekte turizm endüstrisinde, teknoloji ve robot uygulamalarının açık bir hâkimiyeti olacağını göstermektedir. Tamamen olmasa da birçok işgücünde robotlar ve servis otomasyonlarının daha çok artacağı yorumunu

\footnotetext{
${ }^{1}$ Avatar, gerçek bir kişiyi sanal ortamda temsil eden sanal kişi (resim, şekil, grafik) olarak tanımlanmaktadır.
} 
yapmak da mümkündür (Ivanov vd., 2017). Bu nedenle, gelecek kuşakların bugünün turizm tüketim şekillerinden çok farklı ortamlarda ve tüketim şekilleri ile seyahat deneyimlerini yaşayacakları kolayca tahmin edilebilir.

\section{Dijitalleşmede $Z$ ve Alfa Kuşakları}

Tarihsel süreçte yeryüzünde yaşamış ve hâlihazırda yaşamakta olan "kuşaklar" arasındaki ayrımlar genel olarak farklı dönemlerde doğan ve yaşayan insanların yaşam ve tüketim tarzlarında meydana gelen değişikliklere ve bu değişikliklerin söz konusu insan gruplarının yaşamlarını nasıl etkilediklerine göre belirlenmektedir. Bu ayrım, genel olarak çok eski nesillere kadar uzanmayıp son 100 - 150 yıl içinde dünyaya gelmiş olan nesiller itibarıyla yapılmaktadır. Çünkü insanoğlunun yaşamındaki en hızlı değişimler bu son bir asırlık dönemde meydana gelmiştir. Biraz daha

$Z$ ve Alfa Kuşağı ile Dijitalleşen Turizm ayrıntılı tarihsel analizlerde kuşak farklılıklarının ve karşılaştırmalarının 18. yüzyıldaki endüstri devrimine kadar gidilmesi söz konusu olabilmektedir ve 18. yüzyılda yaşanan endüstri devrimi ile oluşan toplum yapısı insanların kırsal alanlardan kentlere yoğun bir şekilde göç etmesi ile sonuçlanmış, buna paralel olarak ortaya çıkan üretim yapısı yeni toplumsal yaşam tarzlarına, tüketim şekillerine ve insan ilişkilerine neden olmuştur. Bu nedenle 18. yüzyıl sonrası kuşaklar, kendilerinden önceki dönemlerde yaşayan nesillere göre çok farklı yaşam koşullarına ve tarzlarına sahip olmuştur. Bu çalışmanın kapsamı, tarihsel olarak geriye doğru giderek o dönem kuşaklarını incelemek değildir. Bu nedenle çalışma turizm tüketimi açısından özellikle 1950 sonrası kuşaklar ile milenyum dönemi adı da verilen ve günümüzün gençlerinden oluşan kuşaklar arasında bir karşılaştırmayı yapmayı ve özellikle de genç kuşakların dijital turizme önceki kuşaklara göre ne kadar daha fazla yatkın olduğunu ortaya koymayı da amaçlamıştır.

Öte yandan, bir kuşak gerçekte bir tüketici grubundan çok daha fazlasıdır. Uzmanlara göre, kuşak kavramı 4 boyutta değerlendirilmelidir; demografik boyut, soyağacına bağlı boyut, tarihsel boyut ve sosyolojik boyut. Buna göre her bir kuşak kuşkusuz içinde bulundukları politik, ekonomik ve kültürel ortamlardan etkilenir ve tarihsel olaylar da yaşam değerlerini şekillendirir (Ladwein vd., 2009'den aktaran Haddouche vd., 2019). Kuşaklarla ilgili en önemli konu, kuşakların birbirlerine göre farklılıklarının ortaya konulmasıdır. Aynı kuşakta anılan nesiller yaşam tarzlarından, iş yapış şekillerine kadar benzer davranışlar sergilemektedirler. Örneğin, genç kuşaklar sabırsız olma ve hemen bir etki yaratma eğilimde iken, orta kuşak kurum aidiyetiyle birlikte kurumun amacına inanır. Yaşlı kuşaklar ise risklerden çekinmekle birlikte, değişiklik ve belirsizlik sevmeyen özellikleri ile ön plana çıkmaktadırlar (Yelkikalan ve Aydın, 2010). Kuşakların yaşama 
Ebru BAĞÇI ve Onur içöz, 3 (2) 2019

- 246 ilişkin bakış açıları incelendiğinde de çok belirgin farklılıklar bulunduğu gözlemlenmiştir (Acılıoğlu, 2015: 29). Örneğin, Sessiz kuşak (1925-1945 arası doğanlar) devamlı hayatta kalma mücadelesi vermiş, Bebek Patlaması kuşağı savaş ve buhran dönemiyle, Soğuk Savaş’ın gölgesinde daha tedbirli ve kontrollü yaşamakla birlikte, aynı şekilde daha tedbirli ve kontrollü harcamalar yapmışlardır. $X$ kuşağı ise, savaş dönemi sonrası kuşak olan "Bebek Patlaması" kuşağının ardından gelen bir geçiş kuşağı olarak, genellikle ebeveynleri tarafından ihmal edilen ve değişen dünyanın dinamiklerini acımasızca tecrübe eden kuşak olarak görülmüştür. Kendilerinden önceki kuşaklara kıyasla daha fazla ekonomik olanaklara sahip olan ve bu olanaklarla yaşamlarını sürdüren $Y$ kuşağı üyeleri ise, hayatın tadını çıkarmak için yaşayan ve bireysel farklılıklarını çalışma yaşamlarına taşımak düşüncesinde olan bireyler olmuşlardır (Aka, 2017: 212).

Günümüzün gençlik kuşağı olarak tanımlayabileceğimiz ve Yeni Sessiz Nesil, Gen Z, Zeds, IGen (Internet Generation) gibi farklı isimlerle anılan Z Kuşağı 2000 yılından itibaren doğan kişiler için yapılmış olan bir tanımlamadır. Bazı yazarlar Z kuşağının isim ve doğum yıl aralıklarında ilerleyen dönemlerde değişiklik olabileceğini de belirtmişlerdir (Jones vd., 2007: 12; Ericsson, 2018 ). Çünkü daha önce yapılan çalışmalarda Z kuşağı 1995-2010 yılları arasında doğan nesil olarak da tanımlanmaktaydı. 1995 yılının Z kuşağı başlangıcı olarak kabul edilmesinde ise temel etken, internet erişiminin ticari amaçla tüm dünyada yaygınlaşmaya başladığı yıl olmasıdır (Sönmez, 2016: 108). Z kuşağı, doğdukları dönemden de kaynaklı olarak teknolojiyi hızlı bir biçimde özümseyen, işleri pratik, titiz ve hızlı bir şekilde yerine getiren, tüm bunlarla birlikte yaşanılan dünyanın sunduğu zevklere fazlasıyla düşkün (hedonist) davranış yapısına sahip özellikleri ile ön plandadırlar. Doğumlarından itibaren yanlarında küçük aygıtlar, Mp3-Mp4 çalarlar, cep telefonları vb. ile büyümektedirler. Sonuç odaklı Z kuşakları aynı zamanda motor becerilerinin senkronizasyonu bakımından da dünya tarihinin bugüne kadar en gelişmiş nesli olarak karşımıza çıkmaktadırlar (Kon, 2018). Z Kuşağının en belirgin özelliği, yaşamları büyük ölçüde Bilgi Teknolojileri, İnternet ve Sosyal Medya tarafından şekillenen ya da yönlendirilen bir kuşak olmasıdır (Haddouche vd., 2018)

Günümüzde Dijital Kuşak (Digital Natives) olarak da tanımlanan Z kuşağı, sadece ABD'de 83 milyonluk bir nüfusu oluşturmaktadır ve yıllık satın alma güçleri ise toplam 200 Milyar dolar kadardır. İçinde bulunduğumuz dönem itibarıyla dünya ekonomisi bakımından da işgücünün en kalabalık grubu olarak dikkat çekmektedirler. Bu kuşaktaki insanlar evlilik, deneyim, siyaset, ekonomi gibi birçok alanda kendilerinden önceki kuşaklar olan $X$ ve $Y$ kuşaklarından yaklaşım olarak ayrılmaktadırlar. Geleneksel yapıya 
tamamen karşı, kişiselleştirme nesli olan Z kuşağı, ortak norm taşıyıcısı olmaktan çok, farklı nitelikleri bünyesinde barındıran bireyler toplamı olarak anılmaktadırlar (Kaynak, 2017). Onlar, sosyal medya, internet, bilgisayar ve cep telefonu gibi birçok elektronik cihazların gelişimine ve yaygın kullanılmasına tanıklık etmişlerdir (Grail Research Report, 2010). Z kuşağı, gerçek ve sanal dünyayı bir bütün olarak görmekte ve iletişimde sosyal medya kanallarını ve yüz yüze iletişimi bir arada kullanmaktadırlar (Sladek ve Grabinger, 2013). Z kuşağı artık birer ebeveyn olacak çağa geldiğinde, o yıllarda genç yaşlarında bulunacak olan ve daha dijital, daha zengin nesil olarak anılmakta olan, 2010 yılı ve sonrasında dünyaya gelenler de literatürde Alfa kuşağı olarak anılmaya başlamıştır. Her hafta 2,5 milyon bireyin aralarına katıldığı Alfa kuşağının sayısının 2025 yılında 2 milyar kişiye ulaşması beklenmektedir (Özeren, 2017). Z ve Alfa kuşaklarının doğumlarından günümüze kadar dijital ve teknoloji dünyasında gerçekleşen Dijitalleşen Turizm buluş ve yenilikler de aşağıdaki tabloda (Tablo 3 ) listelenmiştir (Kayıkçı ve Bozkurt, 2018) .

Tablo 3. Z ve Alfa Kuşağı Dönemi Teknolojik Gelişmeler

\begin{tabular}{|c|c|}
\hline YILLAR & TEKNOLOJIK GELIŞMELER \\
\hline 2000 & $\begin{array}{l}\text { Taşınabilir bellek olan USB flash sürücüler kullanıma sunuldu, Nokia } 3310 \\
\text { piyasaya çıktı. }\end{array}$ \\
\hline 2001 & İnternet ansiklopedisi olarak tanımlanan Wikipedia açıldı. \\
\hline 2002 & Sosyal medya paylaşım sitesi olan MySpace açıldı. \\
\hline 2003 & Sosyal medya video paylaşım sitesi YouTube açıldı. Güneş Çatıları yapıldı. \\
\hline 2005 & Sosyal medya paylaşım sitesi olan Facebook açıldı. \\
\hline 2006 & Sosyal medya kısa metin paylaşım sitesi olan Twitter açıldı. \\
\hline 2007 & $\begin{array}{l}\text { Dijital veri depolama merkezi Dropbox kuruldu, Kindle (e-kitap okuma cihazı) } \\
\text { çıktı, internet bağlantısı sağlayan ilk telefon olan iPhone piyasaya çıktı. }\end{array}$ \\
\hline 2008 & Tesla Roadster akülü (elektrik şarjlı) otomobil üretildi. \\
\hline 2009 & $\begin{array}{l}\text { Telefon üzerinden mesajlaşma uygulaması Whatsapp kuruldu. } \\
\text { Kickstarter (yenilikçilik destekleme sitesi) sitesi kuruldu. }\end{array}$ \\
\hline 2010 & $\begin{array}{l}\text { Müzik dinleme aracı iPad ve Sosyal Medya Paylaşım sitesi Instagram başlatıldı. } \\
\text { illk Drone (İnsansız küçük hava aracı) çıktı. }\end{array}$ \\
\hline 2011 & Mars uzay aracı Curiosity gezegenin yüzeyine bırakıldı. \\
\hline 2012 & Facebook 1 milyar aktif kullanıcıya ulaştı. MaterniT ${ }^{\circledR} 21$ uygulaması çıktı. \\
\hline 2013 & İnsansı Robot denemeleri başlatıldı. Biyonik göz üretildi. \\
\hline 2014 & $\begin{array}{l}\text { Google Glass (Sanal Gerçeklik Gözlüğü) başlatıldı. Kâğıt Mikroskop: Foldskope } \\
\text { üretildi. }\end{array}$ \\
\hline 2015 & $\begin{array}{l}\text { 3D yazıcı temelli üretim başlatıldı. Periscope başlatıldı. Tesla/Powerball çıktı. } \\
\text { Akıllı Ev teknolojileri başladı. }\end{array}$ \\
\hline 2016 & Tesla 3 tanıtıldı. Mobil iletişimde $4.5 \mathrm{G}$ başlatıldı. \\
\hline 2017 & Bükülebilir teknolojik ürünler çıktı. \\
\hline
\end{tabular}


Ebru BAĞÇI ve Onur içöz, 3 (2) 2019

- 248
2018

Yapay embriyolar, 3D metal yazıcılar, çeviri yapan kulaklık, Genetik falcılık ortaya çıktı.

Kaynak: Kayıkçı ve Bozkurt, 2018; Inanç, 2019

Tablo 3'de yer alan teknolojiler ve yenilikler daha da gelişmiş durumları ve kullanım şekilleri ile hem günümüz genç kuşakları olan Z kuşağı, hem de bir sonraki kuşak olan Alfa kuşağının yaşamlarının birer parçası olacağı düşünülmektedir. Bu durumun bu kuşakların seyahat satın alma, seyahat etme, seyahatleri sırasında tüketim şekilleri ve benzeri birçok konudaki kararlarını da yönlendireceği düşünülmektedir. Bu nedenle Turizm endüstrisinde yer alan işletmelerin küresel pazarda rekabet etmelerinin öncüllerinden biri de, bu yeni kuşaklardan oluşacak potansiyel tüketici profillerini iyi analiz etmek ve onlara en etkili şekilde ulaşabilmek ve kendilerine en doğru ürün ve hizmeti sunabilme becerileri ve yeterlikleri olacaktır. Dolayısıyla yakın gelecek içerisinde aktif hedef kitle haline gelecek olan Z kuşağının tüketim eğilimlerinin tanınması önem taşımaktadır. Yapılan araştırmalarda da genç tüketicilerin diğer yaş gruplarına göre teknolojik özellik bakımından gelişmiş ürün ve hizmetleri tercih etme oranları daha fazladır (Spero ve Stone, 2004).

Yapılan araştırmalar, genç turistlerin seyahatlerdeki en belirgin davranışlarının; son dakika kararları, fırsat arayışları, tavsiye (WOM) kullanımı, destinasyonlar hakkındaki tavsiye kaynakları ve düşük maliyetli (low-cost) seyahat araçları üzerine yoğunlaştığını ortaya koymuştur (Haddouche ve Salomone, 2018). Benzer şekilde genç turistlerin "Akıllı Destinasyonlar" olarak tanımlanan bölgeleri ziyaretleri sırasındaki teknolojiye dönük davranışlarının da aşağıdaki alanlarda ortaya çıktığı belirlenmiştir (Femenia-Serra vd., 2019; Dorcic vd., 2019);

1. Mobil teknoloji kullanımı ve web tabanlı uygulamalar üzerinden iletişim

2. Kişiselleştirilmiş deneyimleri ile ilgili veri paylaşımları (kişisel bilgilerin gönüllü ya da gönülsüz olarak işletme ve kurumlarla paylaşımı)

3. Daha ileri dijital deneyimler konusunda akıllı teknolojilerin kullanımı (wi-fi kullanımı, artırılmış/sanal gerçeklik uygulamaları, akıllı etiketler, akıllı kartlar vb. gibi)

Şu anda seyahatlerin önemli bir yüzdesini kapsayan $Y$ kuşağının bu teknolojilere yakınlığı bilinmektedir ve bunlar pazarın Bilgi ve İletişim Teknolojileri (ICT) kullanımı en yüksek dilimi olarak kabul edilirken, Z kuşağının beceri ve beklentilerinin daha ileri olacağını da belirtmek gerekir. 


\section{TARTIŞMA}

Insanların turizm faaliyetlerine katılımları öncelikle bir algı süreci ile başlamaktadır. Turistler, öncelikle tatili için bir destinasyon belirleyip daha sonra tatiline yönelik beklentilerini oluşturmaktadır. Tatile gittikleri zaman ise bu beklentilerini ya da beklentilerinden farklı gelişen durumları yaşamaktadırlar. Bu noktada dijital çağın yardımından faydalanarak turiste yönelik tanıtımlarını gerçekleştiren turizm sektörü paydaşları, turistlerin beklentilerini karşılayıp karşılayamayacaklarını turistlere gösterebilir.

Dijitalleşmeye yönelik bu ve benzeri uygulamalar başta seçenek gibi görülmekteydi ancak günümüzde bireysel tüketici konumuna gelen $Z$ kuşağı ve Alfa kuşağının da etkisiyle bir gerekliliğe dönüşmektedir. Bu gereklilik, turizm sektörü rota belirleyicileri tarafından da sıklıkla gündeme getirilmeye başlamıştır (turizmgazetesi.com, 2016).

Dijital dünyada turizm sektör paydaşlarına yapılan olumlu veya olumsuz yorumlar, turistlerin tercihleri konusunda yüksek belirleyici etken konumundadır. Bu durumu farkına varmış olan işletmeler, kendilerine yapılan yorumları yakından takip edip yorumlayıcılar ile bizzat iletişim kurarak işletmeleri ile ilgili yapılan yorumları önemsediklerini ve yorumlayıcılarının düşüncelerine değer verdiklerini göstermektedirler. $Z$ ve

Z ve Alfa Kuşağı ile Dijitalleşen Turizm Alfa kuşağına dâhil tüketiciler, dijital dünyadaki bu aktifliği yakından takip etmektedirler. Z ve Alfa kuşağı için turizm paydaşlarının dijital alandaki hareketliliği ve her eylemlerine karşılık bulmaları satın alma faaliyetleri esnasında olumlu etkilere neden olmaktadır (Edelman ve Singer, 2019).

$\mathrm{Bu}$ bağlamda, turizm sektöründeki her kategorideki hizmet sağlayıcıların önümüzdeki dönemlerin turistleri, ziyaretçileri ve konukları olacak kuşakların aşağıda belirtilen aşamalardaki tercihlerini belirleme ve yönlendirme yeterlik ve becerileri kendilerinin başarılarınında bir göstergesi olacaktır.

- $\quad$ Seyahat öncesi bilgilenme aşaması. Hangi dijital platformlardan bilgi iletilmektedir, en etkili iletişim şekli ve platformu ne olacaktır?

- Seyahate çıkmayıp sanal seyahat satın alabileceklere nasıl ulaşılabilir, tercihleri neler olacaktır? Bu aşamada ya da bu aşamadan bağımsız olarak seyahat engeli nedeni ile seyahate çıkamayacak olanların sanal seyahat tercihleri nelerdir ve nasıl etkilenebilir? Sanal turizm kategori ve türleri neler olacaktır?

- Seyahate niyetlenme aşaması. Seyahat düşüncesinin oluşmasında ve/veya oluşturulmasında hangi dijital araçlar etkin olacaktır? 
Ebru BAĞÇI ve Onur içöz, 3 (2) 2019

- 250
- $\quad$ Seyahate karar öncesi aşama. Seyahat için hangi alternatifler ne şekilde değerlendirilecektir?

- $\quad$ Seyahat seçenekleri değerlendirme aşaması. Farklı seyahat seçenekleri hangi ortamlarda değerlendirilmektedir, bu aşamada dijital araçların etkisi ve yeri ne alacaktır?

- Seyahat kararı aşaması: Bu aşamada kişisel kararları etkileyebilecek dijital ortamlar ve araçlar neler olabilir?

- $\quad$ Sanal seyahat firmaları (e-acenta) ne ölçüde kullanılacaktır? Fiziki seyahat aracılarının payı ne olacaktır?

- Ulaştırma araçlarında dijital teknolojilerin en etkin kullanımı hangi sanal ortamlarda daha etkili olacaktır?

- Seyahatlerde kullanılan ulaşım araçlarında sanal ve dijital ortamlar neler olacaktır, en iyi hizmet nasıl sunulacaktır?

- Destinasyonlarda transferlerde ya da bölgesel seyahatlerde sürücüsüz araçlar etkin bir şekilde kullanılacak mıdır? Payları ne olacaktır?

- Destinasyonlarda paylaşım ekonomisinin yeri, payı kullanım oranı ne olacaktır? (UBER, AirBNB vb.)

- Konaklama sırasında bu kuşakların temel ihtiyaç ve beklentileri neler olacaktır?

- Destinasyonlarda başlıca tüketim kategorileri için dijital ve sanal ortamlar ne şekilde ve hangi ağırlıkta kullanılacaktır?

- Seyahat edenler kendi deneyimlerini ne ölçüde ve hangi ortamlarda paylaşacaktır? Seyahat yorumlarının (E-WOM) diğer turist adayları üzerinde etkileri ne düzeyde olacaktır?

- $\quad$ Dijital ortamların yeniden seyahatler üzerinde bir etkisi olacak mıdır?

Bunlara ek olarak da aşağıdaki genel konulardaki gelişme ve değişimlerin iyi analiz edilmesi gerekir;

- Yeni kuşakların turizm türü tercihleri değişecek midir? Alternatif turizm türleri neler olacaktır?

- $\quad$ Daha bireysel turizm türü ile kitle turizmi gerileyecek midir?

- Uzay turizmi talebi nasıl olacaktır?

- $\quad$ Denizaltı turizmi ne ölçüde gelişecektir?

- Ekstrem turizm türlerinin talebinde hangi değişmeler olacaktır?

Tüm bu soruların doğru şekilde yanıtlanması hem turizm sektörünün bütünsel olarak gelişmesine, hem de bireysel işletmelerin başarılarına önemli katkıları olacaktır. 


\section{SONUÇ}

Z kuşağı ve sonrasında doğan Alfa kuşağı, doğdukları dönem olan dijital çağda dünyaya gelmiş olmaları nedeniyle diğer nesillere oranla daha fazla akıllı cihazlar, sosyal medya ve internet tabanlı teknolojilerle daha ilgilidirler. Bu anlamda da dijital dönüşümün en fazla etkilediği kuşak olduklarını söylemek yerinde olacaktır. Kendilerinden önceki kuşaklara oranla teknolojik gelişmelere daha uyumlu oldukları söylenebilir. Teknoloji çağı, dijital çağ çocukları olarak geçmişin koşullarına göre değil, geleceğe yönelik belirsizliklerle baş edebilecek düşünme yetisine sahip, problem çözmede yetenekli ve otokontrol mekanizmaları yüksek nesiller olarak yetiştirilmektedirler. Çünkü Z kuşağı ve Alfa kuşağı nesli 3D yazıcılar, giyilebilir teknoloji ürünleri gibi geçmiş kuşaklar için olağanüstü görülen teknolojiler ile doğduklarından beri tanışıktırlar.

Bu çalışma kapsamında yapılan literatür incelemesi sonucu dijitalleşmeye yönelik araştırmaların gün geçtikçe arttığı gözlemlenmiş ve bu bağlamda gündelik yaşamımıza birçok teknolojik ürün girmiştir. Dijital teknolojinin bir uzantısı olan yapay zekâ - insan etkileşimlerinde insan odaklı kavramları anlamlandırmak için mühendislikten sosyal bilimlere kadar birçok alanda iş birlikleri gözlemlenmektedir. Ancak turizmde bu alanda yapılan çalışmaların sınırlı kaldığı gözlemlenmektedir. Oysaki turizm, bu anlamda gelişmelerin rahatlıkla uygulanabileceği bir alandır. Araştırmaların sınırlı kalması dijital teknoloji ve yapay zekâ alanlarındaki gelişmelerin başlangıç süreçlerinin paylaşılmamasından kaynaklı olduğu söylenebilir.

Yapay zekâ ve robot teknolojisine önem veren işletmelerin çağa ayak uydurmaya çalıştığı söylenebilir. Neticede işletmeler bakımından Z ve Alfa kuşakları potansiyel müşteri profilini oluşturmaktadır. Ayrıca dijital çağda zamanla pek çok iş alanının daralacağı, kimi mesleklerin tamamen ortadan kalmasının yanında yeni meslek kollarının da oluşacağı ön görülmektedir. $\mathrm{Bu}$ anlamda da $\mathrm{Z}$ ve Alfa kuşakları iş gören olarak da yer aldıkları günümüzde yer alacakları gelecekte bu dönüşümden etkileneceklerdir.

Yakın geçmişe kadar varlığı ütopik görülen cep telefonları ve internet teknolojisi ile yapılabilecekler bugün hayatımız ayrılmaz birer parçası konumuna gelmiştir. Aynı şekilde yakın gelecekte de yapay zekâ ve robotlar da $Z$ ve Alfa kuşağı ile birlikte o döneme şahitlik edebilecek diğer kuşaklar içinde gündelik yaşamın birer parçası olacaklardır. Turizm sektörü açısından örneklemek gerekirse, hizmet robotu olarak üretilecek yapay zekâ destekli robotlar, müşterilerin oda taleplerine karşılık verebileceklerdir.

Literatürde turizmde dijitalleşme konusunda birçok çalışma ve yayın olmasına karşıık, farklı kuşakların turizmde dijitalleşmeye nasıl yaklaştığı,
Z ve Alfa Kuşağı ile

Dijitalleşen Turizm

- 251 
nası uyum sağladığı ve seyahat öncesi, seyahat sırası ve sonrasında dijital platformlarla nasıl temas kurdukları, özellikle günümüzün ve geleceğin kuşakları olan Z ve Alfa kuşaklarının bu süreçteki tutum ve davranışlarının neler olabileceği konusundaki eksikliğin olduğu görülmektedir. Bu alandaki eksikliğin giderilmesi için bu çalışmanın bir öncü nitelik taşıdığını tahmin ediyoruz. Aynı şekilde, turizm işletmelerinin de bu farklı kuşaklara dijital ortamlarda nasıl ulaşabilecekleri ve onların beklentilerini ne şekilde karşılayabilecekleri konusunda da bu çalışmanın her kategorideki turizm işletmesine bir yol gösterici olmasını ümit ediyoruz.

\section{KAYNAKÇA}

Ebru BAĞÇI ve Onur içöz, 3 (2) 2019

- 252
Acılıoğlu, ì. (2015). “îş"te Y Kuşağı. Ankara: Elma Yayınevi.

Aka, B. (2017). Kamu ve Özel Sektörde Çalışan Yöneticilerin Kuşak Farklılıkları ve Örgütsel Bağlılık Düzeyleri Arasındaki illişkinin İncelenmesi: İzmir ilinde Bir Araştırma (Yayınlanmamış Tez). İzmir Katip Çelebi Sosyal Bilimler Enstitüsü, İzmir.

Biztatar, H. (2017). Olumsuz Elektronik Ağızdan Ağıza Pazarlama Iletişimine Etki Eden Faktörler: Z Kuşağı Tüketicilerinin Görüşlerini Belirlemeye Yönelik Bir Araştırma. Mersin: Çağ Üniversitesi Sosyal Bilimler Enstitüsü.

Boneval, Z. (2019). Dünyadaki ilk robot Otel Japonya'da Açıldı. [URL: http://www.yolculukterapisi.com/dunyadaki-ilk-robot-otel-tabii-kijaponyada-acildi/], (ErişimTarihi: 23 Mayıs 2019).

Cheung, C.W., Tsang, I.T. ve Wong, K.H. (2017). Robot Avatar: A Virtual Tourism Robot for People with Disabilities. International Journal of Computer Theory and Engineering, 229-234.

Del Vecchio, P., Mele, G., Ndou, V. ve Secunda, G. (2018). Creating value from Social Big Data: Implications for Smart Tourism Destinations, Information Processing and Management, 54, 847-860.

Dorcic, J., Komsic, J. ve Markovic, S. (2019). Mobile technologies and applications towards smart tourism - state of the art, Tourism Review, 74(1), 82-103.

Dubey, A.K. (2017). Future Technology and Service Industry: A Case Study of Travel and Tourism Industry. [Global Journal of Enterprise Information System, Informaticjournal.com]. (Erişim Tarihi: 08 Mart 2019). 
Durmaz, C., Bulut, Y. ve Tankuş, E. (2018). Sanal Gerçekliğin Turizme Entegrasyonu: Samsun'daki 5 Yıldızlı Otellerde Uygulama. Turkish Journal of Marketing, 32-49.

Edelman, D. ve Singer, M. (2019). Business-Fuctionas. www.mckinsey.com: [https://www.mckinsey.com/business-functions/marketing-andsales/our-insights/the-new-consumer-decision-journey]. (Erişim Tarihi: 10 Nisan 2019).

Ericsson (2018). Generation Z: Understanding the Digital Lives of India's Young Mobile Users. [www.ericsson.com: Generation Z: Understanding the Digital Lives of India's Young Mobile Users]. (Erişim Tarihi: 09 Kasım 2018).

Erol, G. (2017). X, Y ve Z Kuşağı Tüketicilerinin Satın Alma Davranışları $Z$ ve Alfa Kuşağı ile Dijitalleşen Turizm Üzerine Pilot Bir Araştırma. İstanbul: Beykent Üniversitesi Sosyal Bilimler Enstitüsü.

Femenia-Serra, F., Perles, J.F. ve Ivars-Baidal, J.A. (2019). Smart destinations and tech-savvy millennial tourists: hype versus reality, Tourism Review, 74(1), 63-81.

Haddouche, H., ve Salomone, C. (2018). Generation Z and the tourist experience: tourist stories and use of social networks. Journal of Tourism Futures 4(1), 69-79.

Huang, C.D., Goo, J., Nam, K. ve Yoo, C-W (2017). Smart tourism technologies in travel planning: The role of exploration and exploitation, Information and Management, 54, 757-770.

Hughes, N.C. (2016). How Virtual Reality is About to Transform the Travel Industry. INC: [https://www.inc.com/neil-c-hughes/how-virtualreality-is-ab-transform-the-travel-industry.html]. (Erişim Tarihi: 12 Nisan 2019).

İçöz, O. (2001). Turizm İşletmelerinde Pazarlama: İlkeler ve Uygulamalar, íkinci Basım, Turhan Kitabevi, Ankara.

Inanç, B. (2019). Teknoloji/Bilim. dunyahalleri.com: [https://www.dunyahalleri.com/2018in-cigir-acan-teknolojikgelismeleri/ ]. (Erişim Tarihi: 16 Mayıs 2019).

İsman, A. (2001). Bilgisayar ve Eğitim. Sakarya Üniversitesi Eğitim Fakültesi, 2,

[http://dergipark.ulakbim.gov.tr/sakaefd/article/view/5000003713/5 000004227]. (Erişim Tarihi: 16 Mayıs 2019). 
Ivanov, S.H., Webster, C. ve Berezina, K. (2017). Adoption of Robots and Service Automation by Tourism and Hospitality Companies. Invtur Conference, Aveiro, Portugal.

Ivanov, S. ve Webster, C. (2017). Artificial Intelligence and Service Automation by Travel, Tourism and Hospitality Companies a Costbenefit Analysis. Adoption of robots and service automotion by tourism and hospitality companies. Zangador, Portugal.

Jones, V., Jo, J. ve Martin, P. (2007). Future Schools and How Technology can be used to support Millennial and Generation-Z Students. Dubai: UBiC; 1 . st International Conference of Ubiquitous Information Technology.

Ebru BAĞÇI ve Onur içöZ, 3 (2) 2019

- 254
Kagermann, H., Wahlsterand, W. ve Helbig, J. (2013). Recommendations for Implementing the Strategic Initiative Industrie 4.0. Final Report of the Industrie 4.0 Working Group, 77.

Kayıkçı, M.Y. ve Bozkurt, A.K. (2018). Dijital Çağda Z ve Alfa Kuşağı, Yapay Zeka Uygulamaları ve Turizme Yansımaları. Sosyal Bilimler Metinleri, 54-64.

Kaynak, A. (2017). X, Y, Z yetmez; biraz da Alfa olsun. Mediacat. İstanbul.

Kon, B. (2018). Blog: Kuşakları Anlamak ve Yönetmek. Humanica: [http://www.humanica.com.tr/kusaklari-anlamak-yonetmek/]. (Erişim Tarihi: 16 Kasım 2018).

Lee, Y., Hu, C, Huang, C. ve Duan, L. (2017). The concept of smart tourism in the context of tourism information services, Tourism Management, 58, 293-300.

Maudlin, L. (2019). Tourism revenues depends on digitization, Tourism Review News, [https://www.tourism-review.com/turkey-couldincrease-its-tourism-revenues-news11070], (Erişim Tarihi: 20 Mayıs 2019).

Mil, B. ve Dirican, C. (2018). Endüstri 4.0 Teknolojileri ve Turizme Etkileri. Disiplinlerarası Akademik Turizm Dergisi (3), 1-9.

Nieto, D., Quesada-Arencibia, A., Garcia, C.R. ve Moreno-Diaz, R. (2014). A Social Robot in a Tourist Environment. R. Hervas, S. Lee, C. Nugent, \& J. Bravo, Içinde, Ubiquitous Computing And Ambient Intelligence. Personalisation and User Adapted Services. Lecture Notes in Computer Science.

Özeren, U. (2017). "Alfa Kuşağı" Gelecek Dünya, Gelecek Kuşak. Orav. [http://ekampus.orav.org.tr/blogger/ugurozeren/page/43603/--alfa- 
kusagi---gelecek-dunya--gelecek-kusak], (Erişim Tarihi: 16 Kasım 2017).

Page, S. (2009). Transport and Tourism - Global Perspectives. 3rd Ed., Pearson education, Prentice Hall, Harlow, Essex, UK:

Research, G. (2010). Consumers of Tomorrow Insights and Observations About Generation Z. New York: Grail Research.

Sarı, S., Gürsoy, S., ve Özmen, M. (2016, Haziran). Y Kuşağının Çevrim İçi Satın Alma Davranışları. Bitlis Eren Üniversitesi Sosyal Bilimler Enstitüsü Dergisi, s. 87-104.

Sladek, S. ve Grabinger, A. (2013). Gen Z: The First Generation of the 21st Century has Arrived. [http://xyzuniversity.com/wpcontent/uploads/2014/02/GenZ_Final.pdf.], /Erişim Tarihi: 11 Mart Dijitalleşen Turizm 2019).

Soava, G. (2015). Development Prospects of the Tourism Industry in the Digital Age. Revista Tinerilor Economist (The Young Economists Journal), 101-116.

Soylu, A. (2018). Endüstri 4.0 ve Girişimcilikte Yeni Yaklaşımlar. Pamukkale Üniversitesi Sosyal Bilimler Enstitüsü Dergisi. (32), 43-57.

Sönmez, F. (2016). Sosyal Medyanın, Z Kuşağı Tüketicilerinin Satın Alma Davranışları Üzerindeki Etkisi. Manisa Celal Bayar Üniversitesi Sosyal Bilimler Enstitüsü. Manisa.

Spero, I. ve Stone, M. (2004). Agents of Change: How Young Consumers are Changing the World of Marketing. Qualitative Market Research: An International Journal, 7(2), 153-159.

Szopiński, T., ve Staniewski, M. W. (2016, February 1). Socio-economic factors determining the way e-tourism is used in European Union member states. Internet Research, s. 2-21.

Şahin, N.N. ve Doğdubay, M. (2017). 4. Endüstri Devriminin Yiyecek ve İçecek Sektöründeki Yansıması: Yeni Üniversiteliler Üzerine Bir Öngörü. 3. Turizm Şurası Tebliğler Kitabı, 100-114.

Şahin, N. ve Yağcı, P. (2017). Endüstri 4.0 Kavramında Prosumer Kavramının Yiyecek iç̧ecek Sektörü Açısından Değerlendirilmesi. Journal of Recration and Tourism Research, 12-22.

Taşçı, M. (2018). Haber. Projem: [http://www.projem.com.tr/haber/450/gelecegin-akilli-otelleriboyle-olacak], (Erişim Tarihi: 19 Mayıs 2018). 
Tfaily, R. A. (2018, May). E-Tourism and the competitiveness of tourism products in the context of the global tourism and travel industry Market. Review of International Comparative Management, s. 187195.

Titan, L. S., Sanjaya, ve Ferdianto. (2016). Influential Factors on Travel Decision in E-Tourism. 2016 International Conference on Information Management and Technology (ICIMTech) (s. 272-276). Bandung: The Institute of Electrical and Electronics Engineers (IEEE).

Topsakal, Y., Yüzbaşıoğlu, N. ve Çelik, P. (2018). Turizm 4.0 - Turist 5.0: Insan Devriminin Neden Endüstri Devlerimlerinden Bir Numara Önde Olduğuna Iliş̧kin Bakış. Journal of Tourism Intelligence and Smartness,

Ebru BAĞÇI ve Onur içöZ, 3 (2) 2019

- 256 1-11.

Turizmajansı.com (2018). [https://www.turizmajansi.com/haber/otellerdedijital-donusum-basladi-h22835]. (Erişim Tarihi: 10 Nisan 2019).

Turizmgazetesi.com (2016). [URL:https://www.turizmgazetesi.com/news.aspx?id=79863\#myAnch or] (Erişim Tarihi: 05 Mart 2019).

Tüzünkan, D. (2019). Turizm 4.0, İçinde: Turizm Ansiklopedisi - Türkiye: Turizmin ve Ağırlama Endüstrisinin Temel Kavramları, Editörler: İçöz, O. ve Uysal, M., ss.521. Detay Yayıncılık, Ankara.

Üçüncü Turizm Şurası (2017). Dijital Turizm ve İnovasyon Komisyonu. T.C. Kültür ve Turizm Bakanlığı. Tebliğler Kitabı, Cilt 2, ss.98-196, Ed. Tuna, M., Özel Matbaası, Ankara.

Xiang, Z. (2018, January). From digitization to the age of acceleration: On information technology and tourism. Tourism Management Perspectives, s. 147-150.

Yelkikalan, N. ve Aydın, E. (2010). Aile İşletmelerinin Yaşamlarını Sürdürebilmesinde Sonraki Kuşakların Duygusal Sahiplik Algılamasının Rolü ve Önemi: Türkiye'deki Kıdemli İşletmeler Üzerine Bir Araştırma. Yönetim Bilimleri Dergisi, 81-120. 